\title{
Labor's Liquidity Service and Firing Costs
}

\author{
Herman Z. Bennett
}



IMF Working Paper

European Department

\title{
Labor's Liquidity Service and Firing Costs ${ }^{1}$
}

\author{
Prepared by Herman Z. Bennett
}

Authorized for distribution by James Daniel

May 2007

\begin{abstract}
This Working Paper should not be reported as representing the views of the IMF. The views expressed in this Working Paper are those of the author(s) and do not necessarily represent those of the IMF or IMF policy. Working Papers describe research in progress by the author(s) and are published to elicit comments and to further debate.
\end{abstract}

This paper proposes a new effect of firing costs on firms' behavior that builds from firms' demand for liquidity. When a time gap exists between production and its associated revenues, firing can become a liquidity adjustment tool that allows firms to increase their short-term liquidity. I refer to this feature as labor's liquidity service. The presence of firing costs reduces the value of labor's liquidity service, which affects firms' demand for liquidity, and thus, firms' demand for inputs. In addition to this negative effect at the creation margin, I also show that firing costs imply relatively higher destruction for financially restricted firms. I present a model that develops these ideas and show that the presence of firing costs has a stronger negative effect on production levels of firms facing liquidity constraints. Regression analysis, based on country industry panel data sets, provides empirical evidence in line with the liquidity service effect of firing costs proposed. I reject the null hypothesis that the effect of firing costs does not depend on the presence of financial restrictions. I find a relatively stronger negative effect of firing costs on the output of industries with higher liquidity requirements and a relatively stronger negative effect of firing costs on the output of small firms.

JEL Classification Numbers: E23, E24, E61, J65, J23

Keywords: Firing Costs, Financial Restrictions, Liquidity Constraints, Labor's Liquidity Service, Empirical Evidence, Labor Policy

Author's E-Mail Address: hbennett@imf.org

\footnotetext{
${ }^{1}$ I am grateful to Olivier Blanchard, Ricardo Caballero, and Guido Lorenzoni for valuable discussions and helpful advice. Comments from Daron Acemoglu, Daniel Hojman, William Hawkins, Borja Larrain, and from seminar participants at MIT, BIS, IADB, are also greatly appreciated. Claudio Raddatz kindly provided the necessary data on cash conversion cycle. Arlene Tayas' effective help providing the necessary editorial assistance for this working paper version is very much appreciated. All errors are my own. The opinions presented should not be attributed to the International Monetary Fund, its Executive Board, or its management. Comments welcome to hbennett@imf.org.
} 


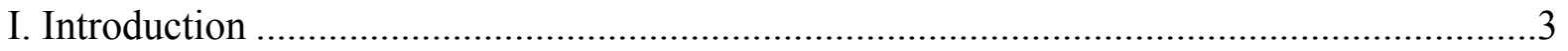

II. Labor's Liquidity Service and Firing Costs .............................................................5

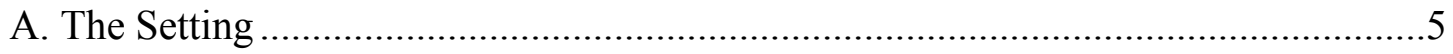

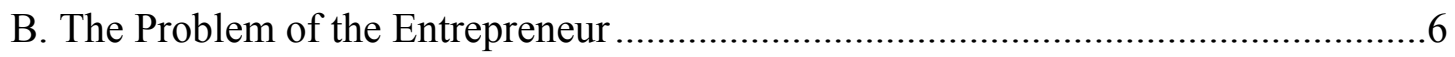

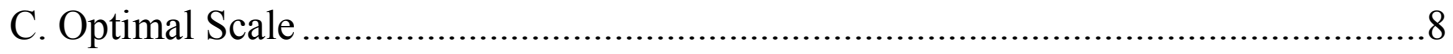

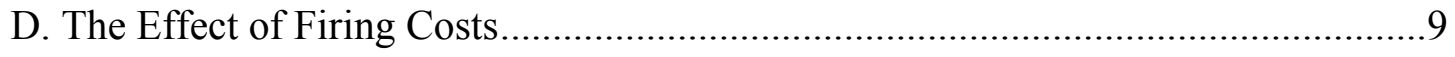

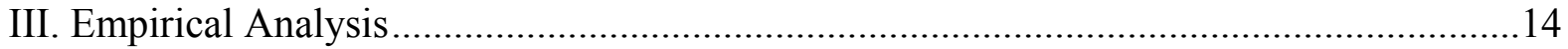

A. Empirical Analysis: Liquidity Requirements................................................16

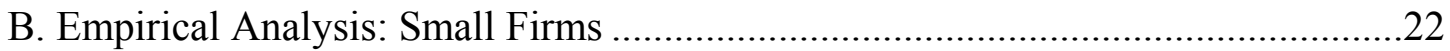

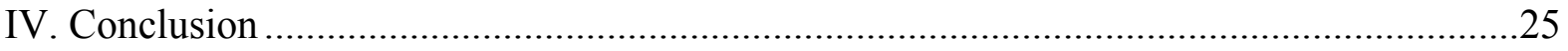

Tables

1. The Effect of the Interaction Between Firing Costs and Liquidity Requirements: Main Results ...................................................................................................... 18

2. The Effect of the Interaction Between Firing Costs and Liquidity Requirements: Robustness Checks..............................................................................................20

3. The Effect of the Interaction Between Firing Costs and Liquidity Requirements: Asset Collateralization .................................................................................21

4. The Effect of Firing Costs on Small Firms' Market Participation: Main Results ...............24

Figures

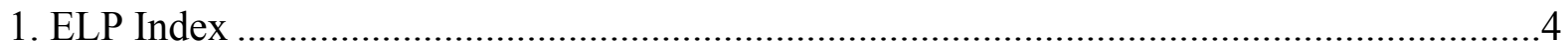

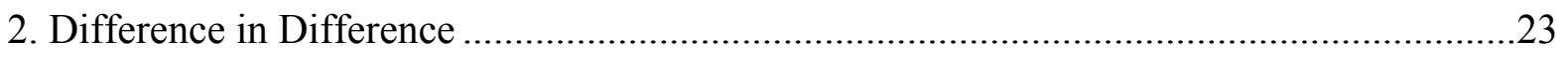

Appendixes

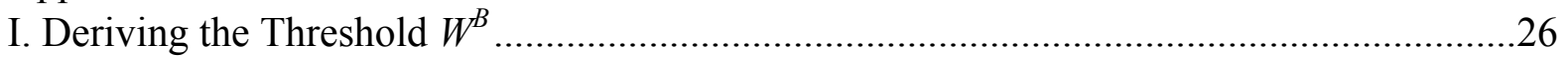

II. The Effect of Optimal Scale on the Expected Value of Labor.........................................28

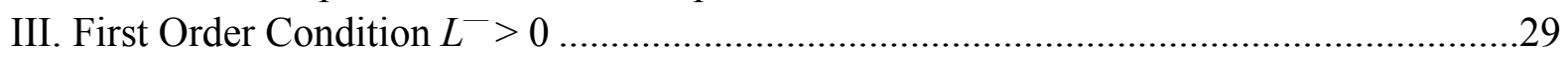

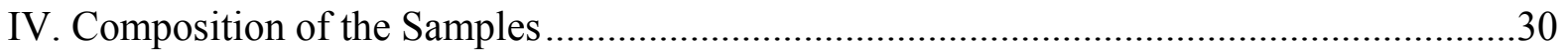

Appendix Tables

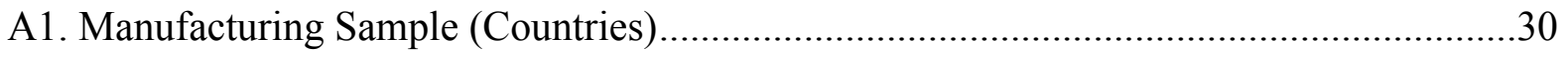

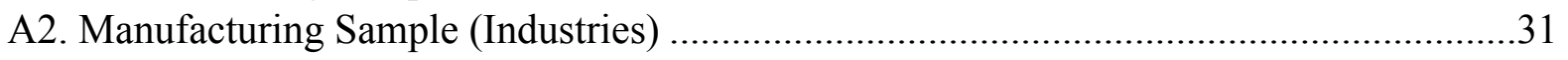

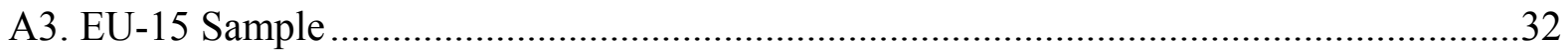

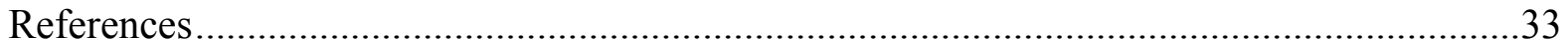




\section{INTRODUCTION}

The firing costs literature highlights two mechanisms by which firing costs affect firms' behavior: i) the efficiency cost created by the incentive to keep workers with expected marginal productivity below their wage (Bentolila and Bertola 1990 and Lazear 1990); and ii) the effect that firing costs have on the bargaining process between employees and employers (Caballero and Hammour 1998 and Blanchard 2000). This paper suggests an additional and independent mechanism that builds from firms' demand for liquidity. The presence of financial restrictions, and the resulting demand for liquidity, has been documented in the finance-related literature (Lamont 1997, Rauh 2005, among others). However, financial restrictions have been largely absent from the discussion of labor regulation.

The conventional views describe firing as an instrument either to adjust production to its efficiency level, or as a bargaining tool. When a time gap exists between production and its associated revenues, firing can also be understood as a liquidity adjustment tool that allows firms to increase their short-term net working capital. In other words, net liquidity is created by firing. From this perspective, a firm in need of liquidity might find it convenient to fire a worker even if his expected marginal productivity (in present value) is higher than his wage. This would allow the firm to increase its net liquidity position, and as a result, relax its financial restriction. I define this feature as labor's liquidity service.

The value of labor's liquidity service is affected by the presence of firing costs. On the one hand, higher firing costs imply that more labor separations (potentially costly separations) will be needed per unit of liquidity raised by firing. On the other hand, higher firing costs could lock a firm into unavoidable situations, such as forced liquidation or the inability to invest in more profitable endeavors with minimum-scale requirements. Thus, the presence of firing costs reduces the value of labor's liquidity service, which in turn affects firms' demand for liquidity and reduces firms' demand for inputs (a downward scaling effect). I define this effect as liquidity service effect of firing costs.

In the case of a firm with enough internal financial resources, or with access to enough external sources of finance, an increase in firing costs will not have the above-mentioned effect. No financial restrictions are present in such a case; the demand for liquidity is zero, and therefore, the effect of the interaction between firing costs and financial restrictions does not operate.

This paper develops a model that studies the liquidity service effect of labor and the differentiated impact of dismissal costs on firms' optimal levels of production when financial restrictions are present. It shows how the negative effect of the interaction between firing costs and financial restrictions on production/efficiency operates. This negative effect occurs at the creation and destruction margins, yielding an unambiguous negative effect of firing costs on production levels; in contrast to the ambiguous effect of firing costs on production described in Bentolila and Bertola 1990 and Lazear 1990. 
Figure 1. ELP Index

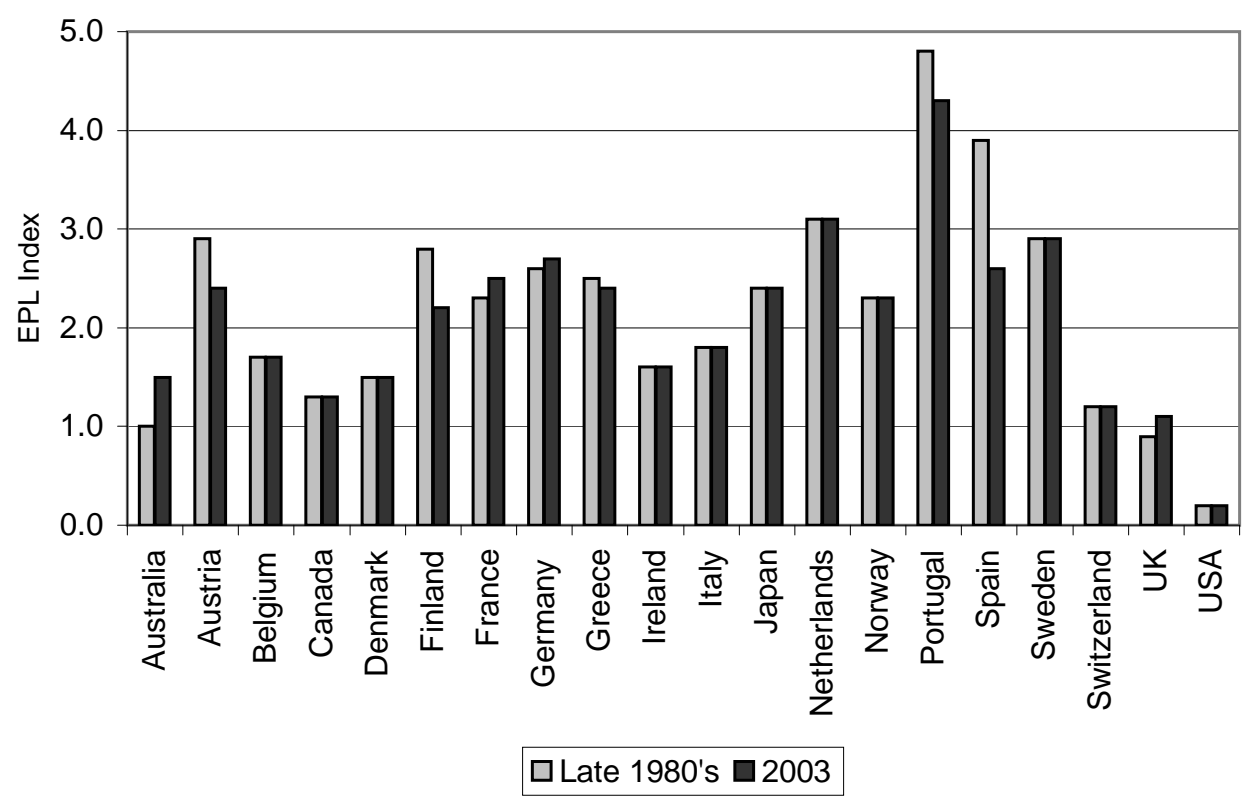

Note: The ELP index corresponds to OECD's of strictness of employment protection for regular employment. Source: Employment Outlook, OECD (2004).

Empirical evidence in line with the liquidity service effect of firing costs is reported. I test the null hypothesis that the effect of firing costs does not depend on the presence of financial restrictions. I reject this hypothesis in favor of the alternative hypothesis that, controlling for the individual effects of firing costs and financial restrictions, the presence of financial restrictions implies a relatively stronger negative effect of firing costs on output (value added). Based on a country-industry (manufacturing) panel data, I find a relatively stronger negative effect of firing costs on value added of industries with higher liquidity requirements. In addition, using a country-sectoral (retail and wholesale trade) panel data with desegregate information for different types of firms according to size, I find a relatively stronger negative effect of firing costs on small firms' output (value added).

Employment protection legislation (EPL), in the form of dismissal procedures and severance-penalty payments, is present in many countries around the world. Figure 1 graphs OECD's EPL for countries with available data. The ELP index shows the well known presence of high employment protection levels in some European countries vis-a-vis the USA. Overall, the data do not present a significant declining trend during the last decade (the average value for the late 1980's is 2.2 and for 2003 is 2.1).

The presence of employment protection, plus the existing evidence in the finance-related literature that liquidity is important for many firms, suggests that the liquidity service effect of firing costs can have important macroeconomic aggregate effects. It can affect the medium growth rate of an economy and also its transitional dynamics. The effects on the speed of employment recovery after a recession can be of particular 
interest. Some facts suggest that these effects can be important: i) small firms' employment levels represent an important share of total employment and total gross job creation (e.g.: in the USA, small firms with 10249 employees represent approximately 30\% of total employment, and small firms with 20-99 employees represent approximately $22 \%$ of total gross job creation); and ii) smaller firms tend to have significantly less, and more pro-cyclical, credit access than larger firms (Gilchrist and Gertler 1994). ${ }^{1}$

This paper also draws implications for welfare analysis of labor policy. Hopenhayn and Rogers (1993), and the literature that followed ${ }^{2}$, characterize the welfare effect of firing costs in neoclassical general equilibrium models where capital accumulation is only indirectly affected by firing costs-firing costs affect employment levels and employment levels affect the marginal productivity of capital. When considering the liquidity service effect of firing costs, a new and potentially important effect arises: The presence of firing costs have a direct effect, through the firms' cash flow constraint, on the optimal capital accumulation level of financially restricted firms.

The rest of the paper is organized as follows. Section 2 presents a 3-period model that studies the liquidity service effect of firing costs. Section 3 describes the empirical strategy and presents the main empirical results and robustness checks. Section 4 concludes and discusses implications for labor policy design.

\section{LABOR's LiQUidity SERVICE ANd Firing COSTS}

\section{A. The Setting}

Assume an entrepreneur that starts period 1 with initial wealth $W$ and has access to a profitable investment project. The project lasts for 3 periods (investment, production, and output), uses labor and capital in fixed proportions (Leontief technology), and has constant returns to scale.

In period 1 , the entrepreneur sets up a firm to undertake the project and chooses the project's scale $H-$ the firm operates under conditions of limited liability, and the scale of the project has a maximum size of $\bar{H}$. Given the scale chosen, the firm hires $H$ workers (e.g.: trainee and start-up duties), and pays $e H$ for this investment (e.g.: plant and wages). The firm can fire workers in period 2 in order to keep only $L \leq H$ workers for production. The firm's labor-related cash outflow in period 2 is then $\omega L+\psi(H-L)$, where $\psi$ represents the level of firing costs faced by the firm $(\psi \geq 0)$. Note that the production technology assumes that production cannot be increased instantaneously (e.g.: the necessary equipment needed per worker takes

\footnotetext{
${ }^{1}$ The estimates of small firms' importance are based on data from the US Bureau of Labor Statistics and from Davis et al. (1996).

${ }^{2}$ Alvarez and Veracierto (2001), Veracierto (2001), Ljungqvist (2002), Jeong (2003), Pries and Rogerson (2005), among others.
} 
one period to be installed). In period 3, the firm output is $F(L)=A L$.

The project is not free of uncertainty from the financial side. In period 2, the entrepreneur faces a stochastic liquidity shock $Z$ that hits her level of wealth. This liquidity shock is private information for the entrepreneur-a highly valued investment or consumption opportunity (following Diamond and Rajan 2001). As a result, the disposable wealth of the entrepreneur in period 2 is $W-e H-Z$, where $Z \sim U[\underline{Z}, \bar{Z}] .{ }^{3}$

Following Hart and Moore (1994), I assume that the outcome in period 3 is not verifiable (private information), and that firm's investment is specific to the entrepreneur. Due to the fact that the entrepreneur cannot contract upon the firm's future outcome, the access to external sources of finance is limited.

As a result of these last two assumptions, the entrepreneur has to cover the liquidity requirements of period 2 with her disposable wealth. If these liquidity needs are not financed, the entrepreneur is forced to liquidate the firm. This financial restriction creates a demand for liquidity in period 1, with the purpose of building a cash buffer stock to face the uncertainty in period 2 (insurance purposes).

\section{B. The Problem of the Entrepreneur}

The problem of the entrepreneur can be written as follows. Given $W$, the entrepreneur maximizes the value of the firm: ${ }^{4}$

$$
V(W)=\max _{H, \mathbb{I}(\cdot), L(\cdot)}-e H+\mathbb{E}(F(L)-\omega L-\psi(H-L))(1-\mathbb{I})
$$

Subject to:

$$
\begin{gathered}
H \leq \bar{H} \quad L \leq H \\
W-e H-Z \geq \omega L+(H-L) \psi \quad \text { if } \mathbb{I}=0 \\
W \geq e H
\end{gathered}
$$

Where the control variable $\mathbb{I}$ takes the value of 1 if the entrepreneur liquidates the firm in period 2 or the value of 0 if she does not liquidate.

Once the entrepreneur has decided the firm's scale in period 1, in period 2 she has to decide the optimal labor force $L$. The marginal cost of an extra unit of $L$ is either the full cost of liquidation or $\omega-\psi$. With respect to the decision in period 1, note that the marginal cost of an additional unit of $H$ is always higher than or equal

\footnotetext{
${ }^{4}$ This formulation is equivalent to assuming a risk neutral entrepreneur that maximizes the sum of her consumption from period 1 to period 3 .
} 
to $e+\omega$ (higher because of the possible costs associated with the presence of financial restrictions). This is true only until the net benefit of staying in business is higher or equal to the net benefit of liquidating the firm. Since the firm is under conditions of limited liability, the entrepreneur may find it convenient to liquidate the firm if the restructuring needed is big enough.

Thus, in period 2 the optimal strategy for the entrepreneur is to hit the corner given by $H$ or by the financial restriction, unless the necessary restructuring makes the project unprofitable. With this in mind, the optimal decision in period 2 can be written as:

$$
L(W, H)= \begin{cases}H, & \text { if } Z \leq Z^{F} ; \\ \frac{W-Z-H(e+\psi)}{\omega-\psi}, & \text { if } Z^{F} \leq Z \leq Z^{L} ; \\ 0 \text { (liquidation), } & \text { if } Z^{L}<Z .\end{cases}
$$

Where $Z^{F}$ and $Z^{L}$ are given by:

$$
\begin{aligned}
& Z^{F}(W, H)=\min \{W-e H-\omega H, \bar{Z}\} \\
& Z^{L}(W, H)=\min \{W-e H-\psi \theta H, \bar{Z}\},
\end{aligned}
$$

and $\theta$ is defined as $\theta \equiv \frac{A}{A-\omega+\psi}$.

The function $Z^{F}(W, H)$ represents the maximum size of the liquidity shock, such that an entrepreneur with a firm of size $H$, and resources $W-e H$ at the beginning of period 2, can finance herself throughout the project. If $Z>Z^{F}(W, H)$ the entrepreneur does not have access to enough liquidity, unless she creates internal liquidity by firing part of the firm's labor force. Faced with this situation, the entrepreneur's optimal decision is to finance the firm by reducing its scale to $L$ and firing $H-L$ workers.

The entrepreneur could continue financing the project only if the liquidity shock is not larger than $\mathrm{W}-e \mathrm{H}-$ $\psi H$ - when even firing all the work force does not create enough liquidity to finance a higher cash outflow in period 2. However, the entrepreneur will not necessarily finance the firm at that level of the liquidity shock, because she might find it convenient to liquidate the firm before reaching that point. The threshold level of the liquidity shock $Z^{L}(W, H)$, such that the entrepreneur decides to liquidate for any higher level, is given by the following condition: $A L-L \omega-\psi(H-L) \geq 0$. That is, staying in business is at least as profitable as liquidating the firm. Given the optimal level of labor in period 2, we can solve for $Z^{L}(W, H){ }^{5}$

The problem of the entrepreneur represented in equation 1 can be rewritten as:

$$
V(W)=\max _{H \leq \bar{H}}-e H+\int_{\underline{Z}}^{Z^{L}(W, H)} F(L)-\omega L-(H-L) \psi d G(z)
$$

\footnotetext{
${ }^{5}$ Note that $\omega \geq \theta \psi$, which implies that $Z^{F}(W, H) \leq Z^{L}(W, H)$ (strong inequality unless $\left.\psi \geq \omega\right)$.
} 
Subject to the set of restrictions in equations 2 and 3 and to $W \geq e H$.

\section{Optimal Scale}

The first order condition (FOC) for the problem of the entrepreneur can be expressed as:

$$
\begin{aligned}
0=-e+\int_{\underline{Z}}^{Z^{F}(W, H)}(A-\omega) d G(z)+ & \\
& \int_{Z^{F}(W, H)}^{Z^{L}(W, H)}\left[(A-\omega) \frac{-(e+\psi)}{\omega-\psi}-\psi\left(1-\frac{-(e+\psi)}{\omega-\psi}\right)\right] d G(z)
\end{aligned}
$$

The first line in equation 5 represents the standard FOC of a firm in an economy without capital market imperfections (pledgeable outcome). In this economy, enough funds would always be available as long as the project has a positive net present value $\left(Z^{F}=Z^{L}=\bar{Z}\right)$. The optimal scale $H$ in this first best world would be given by $\bar{H}$.

The second line in equation 5 represents the marginal effect of increasing the scale $H$ in period 1 on the expected cost of restructuring (in the states of nature where a downward scaling is necessary to create liquidity). The first term in the integral represents the cost associated with the net marginal income loss due to the marginal increase in production destruction. The second term represents the marginal increase in firing cost expenses due to the marginal increase in destruction.

For all states of nature where the liquidity shock in period 2 is above $Z^{L}(W, H)$, the entrepreneur liquidates the firm and faces a continuation value of zero.

The first best allocation $\bar{H}$ is not restricted to firms in economies with perfect capital markets. In an economy with capital market imperfections, entrepreneurs with a strong financial position also choose the optimal allocation $\bar{H}$. In this model, entrepreneurs with a strong financial position are defined as entrepreneurs with initial wealth $W$, such that: ${ }^{6}$

$$
W \geq \bar{W}=\bar{H}(e+\omega)+\bar{Z}-\frac{(A-\omega-e)(\omega-\psi)}{(A-\omega+\psi)(e+\omega)}(\bar{Z}-\underline{Z})
$$

Solving for $H$ in equation 5 determines the firm's optimal scale $H^{*}$ when $W \leq \bar{W}$. In deciding the optimal

\footnotetext{
${ }^{6}$ Depending on the parameter values, the minimum $W$, such that $H^{*}=\bar{H}$, could imply that $Z^{L}(W)=\bar{Z}$ or that $Z^{L}(W)<\bar{Z}$. If $\bar{H} \geq \frac{(A-\omega-e)(\bar{Z}-\underline{Z})}{(A-\omega)(e+\omega)}$, then $Z^{L}(W)=\bar{Z}$. That is, if the maximum size of the project is sufficiently high, then the minimum $W$, such that $H^{*}=\bar{H}$, implies that $Z^{L}(W)=\bar{Z}$. Without loss of generality, and in order to simplify the presentation, I am going to assume that this condition holds.
} 
scale, the entrepreneur faces a trade-off between expanding the initial investment to increase profitability in the good states of nature, and taking a more conservative investment policy to reduce the cost of restructuring, or even liquidation, in the bad states of nature. The risk of the marginal unit of $H$ decreases as initial wealth increases. As a result, the initial investment responds positively to an increase in initial wealth.

This trade-off is confirmed with the closed solution for $H^{*}$.

$$
H^{*}(W)= \begin{cases}\frac{\bar{H},}{W-\bar{Z}+\frac{(A-\omega-e)(\omega-\psi)}{(A-\omega+\psi)(e+\omega)}(\bar{Z}-\underline{Z})} & \text { if } \bar{W} \leq W ; \\ \frac{W+W}{W-\bar{Z}+\frac{(A-\omega-e)}{(A-\omega)}(\bar{Z}-\underline{Z})} & \text { if } W^{B} \leq W \leq \bar{W} ; \\ e+w+\frac{(e+\psi)}{(A-\omega+\psi)}\left(A-\omega+(e+\omega) \frac{\psi}{e+\psi}\right) & \text { if } W \leq W^{B} .\end{cases}
$$

Where $W^{B}=\bar{Z}+\frac{(A-\omega-e)(A e-\omega e+\psi e+A \psi)}{(A-\omega+\psi)(e+\omega)(A-\omega)}(\bar{Z}-\underline{Z})$ is a threshold level of initial wealth $W$ such that below $W^{B}$ it is true that $Z^{L}(W)<\bar{Z}$, and above $W^{B}$ it is true that $Z^{L}(W)=\bar{Z}$. Appendix 1 shows the details of this derivation.

As expected, the optimal scale $H^{*}$ increases with the level of initial wealth $W$ (strong inequality within the interior solution range):

$$
\frac{\partial H^{*}}{\partial W} \geq 0
$$

The response of the optimal scale to an increase in initial wealth is higher at high levels of $W\left(W>W^{B}\right)$. This is explained by the fact that there is no risk of liquidation when $W>W^{B}$.

This scale decision under the presence of financial restrictions parallels a portfolio problem: the entrepreneur decides how much of her wealth $W$ to allocate in the high-return and high-risk asset $(H)$, or in the low-return and low-risk asset (cash-liquidity). There are two additional elements in this case: i) the scale $H$ and the marginal risk of an additional unit of $H$ are positively related; and ii) the level of initial funds $W$ and the marginal risk of an additional unit of $H$ are inversely related.

\section{The Effect of Firing Costs}

In this model firing costs have two effects. On the one hand, an increase in firing costs makes the restructuring more costly. For each worker in excess that the firm hires in period one (that has to be fired in the restructuring 
region), the firm has to fire $\frac{e+\psi}{\omega-\psi}$ additional workers. The numerator $(e+\psi)$ represents the amount of liquidity used by each worker in excess, and the denominator $(\omega-\psi)$ represents the amount of net liquidity raised by firing an additional worker.

If $\psi=0$, the entrepreneur is fully flexible to accommodate the liquidity resources allocated to labor in period 1. In the bad states of nature, she can transform each dollar assigned to wages in period 2 into a dollar of liquidity. As $\psi$ increases, the value of this liquidity service decreases. Creating liquidity by firing is additionally taxed and more restructuring is needed to cover the same liquidity requirements in period 2 . In the limit as $\psi \rightarrow \omega$, labor hired in period 1 becomes a fully fixed production factor and $Z^{L} \rightarrow Z^{F}$.

On the other hand, an increase in firing costs decreases the region of restructuring (by increasing the region of liquidation), and increases the cost of liquidation. This last effect only applies to entrepreneurs with sufficiently low level of initial wealth $\left(W \leq W^{B}\right)$.

In summary, the presence of firing costs affects the firm by making the restructuring process more costly and increasing the liquidation risk. As a result, it creates the incentive to have a more conservative investment/employment policy (downward scale effect). This argument is checked by differentiating equation 6 . 7

$$
\frac{\partial H^{*}}{\partial \psi} \begin{cases}<0, & \text { if } W \leq \bar{W} \\ =0, & \text { if } W>\bar{W} .\end{cases}
$$

The optimal scale of an entrepreneur with a strong financial position $(W>\bar{W})$ is not affected by the presence of firing costs. Given her financial resources, either the risk of restructuring is zero, or small enough that the higher expected return compensates the risk at scale $\bar{H}$.

The result of firing costs having no effect on unrestricted firms is not a general result. To simplify and highlight the presentation of the liquidity service effect of firing costs, the model presented in this paper shuts down the pure efficiency effect of firing costs (by eliminating the stochastic component of labor productivity).

\section{Less creation. Less destruction?}

Firing costs reduce the firms' willingness to hire workers but they also reduce the firms'incentives to fire workers - a key feature of dynamic models of firing costs. This point is well summarized in Bentolila and Bertola's (1990) model, which shows that an increase in firing costs reduces the creation of employment

\footnotetext{
${ }^{7}$ To see the effect in the case that $W \leq W^{B}$, note that a necessary condition for the project to be profitable is that $A-\omega>e$.
} 
and at the same time reduces the destruction of employment, yielding an ambiguous effect on steady state employment level. ${ }^{8}$

The creation-destruction view can be applied to the model presented in this paper. We can interpret the result presented in equation (7) as a financially-related negative effect of firing costs on employment creation $\left(\frac{\partial H^{*}}{\partial \psi}\right)$. There are two channels in which we can see the effect of firing costs on employment destruction: i) on the effective scale of production in period 2 (after the realization of the liquidity shock); and ii) on the optimal scale in period 1 assuming that the firm starts period 1 with a labor force greater than zero. Both channels produce a relatively higher increase in employment destruction for financially constraint firms, yielding an overall unambiguous negative effect of the interaction between firing costs and financial restrictions on production levels.

\section{Effective scale of production in period 2}

From equation 7 we know that the optimal scale $H^{*}$ reduces as the level of firing costs increases (for a given level of initial wealth). However, a reduction in $H^{*}$ implies less risk of restructuring and/or liquidation in period 2. That is, the expected value of labor in the second period, $\mathbb{E} L$, could be lower because of lower $H^{*}$, or could be higher because of lower need of destruction. There is an additional effect to these dynamics: for a given level of $H^{*}$, an increase in firing costs increases the level of destruction in the second period. This last effect goes unambiguously in the direction of lowering $\mathbb{E} L$.

We can use the 3-period model presented in this paper to study these dynamics. In this setting, the expected value of labor in the second period is defined as follows.

$$
\mathbb{E} L^{*}=\int_{\underline{Z}}^{Z^{F}} H^{*} d G(z)+\int_{Z^{F}}^{Z^{L}} L\left(H^{*}\right) d G(z)
$$

Note that the expected value of labor in period 2 can be written as a function of the optimal scale in period 1 and the level of firing costs: $\mathbb{E} L^{*}=\Lambda\left(H^{*}(\psi), \psi\right)$. Therefore,

$$
\frac{\partial \mathbb{E} L^{*}}{\partial \psi}=\frac{\partial \Lambda\left(H^{*}, \psi\right)}{\partial H^{*}} \cdot \frac{\partial H^{*}}{\partial \psi}+\frac{\partial \Lambda\left(H^{*}, \psi\right)}{\partial \psi}
$$

The first term in equation 9 represents the first two effects mentioned before. That is, the indirect effect that firing costs have over the expected production level in period 2-through the effect that firing costs

\footnotetext{
${ }^{8}$ In their calibrations, Bentolila and Bertola find that firing costs have a small, positive effect on steady state employment level.
} 
have over $H^{*}$, and $H^{*}$ over $\mathbb{E} L^{*}$. In the present model, the effect of reducing $H^{*}$ in period 1 dominates the corresponding reduction in production destruction in period 2.

$$
\frac{\partial \Lambda\left(H^{*}, \psi\right)}{\partial H^{*}}>0
$$

Appendix 2 shows the details of this derivation. We already know that $\frac{\partial H^{*}}{\partial \psi}<0$, so the indirect effect of firing costs on $\mathbb{E} L^{*}$ is also negative.

The third effect mentioned-that for a given level of $H^{*}$, an increase in firing costs increases the level of destruction in the second period-reinforces the result implied by equation 10. As a result,

$$
\frac{\partial \mathbb{E} L^{*}}{\partial \psi}=\frac{\partial \Lambda\left(H^{*}, \psi\right)}{\partial H^{*}} \cdot \frac{\partial H^{*}}{\partial \psi}+\frac{\partial \Lambda\left(H^{*}, \psi\right)}{\partial \psi}<0
$$

Thus, an increase in firing costs reduces the firm's initial investment/employment decision, as well as the expected level of production in period 2. In other words, the effective creation level, associated to $\mathbb{E} L^{*}$, responds negatively to an increase in firing costs.

\section{Optimal scale and firing in period 1}

How does the optimal scale $H^{*}$ change if the firm starts period 1 with a labor force of size $L^{-}>H^{*}$ ? In the model presented in this paper, this scenario would create an incentive to reduce destruction, as in the models with no financial restrictions like Bentolila and Bertola's 1990. However, the incentive to reduce destruction is smaller than the one created in the standard models of firing costs. Even more, for certain parameter values, the fact that $L^{-}>H^{*}$ can become an incentive to increase, instead of reduce destruction.

When $L^{-}>H^{*}$, the problem of the entrepreneur can be written as follows. Given $W$ and $L^{-}$, the entrepreneur maximizes the value of the firm:

$$
V\left(W, L^{-}\right)=\max _{H, \mathbb{I}(\cdot), L(\cdot)}-e H-\psi\left[L^{-}-H\right]^{+}+\mathbb{E}(F(L)-\omega L-(H-L) \psi)(1-\mathbb{I})
$$

Subject to:

$$
\begin{gathered}
H \leq \bar{H} \quad L \leq H \\
W-e H-\psi\left[L^{-}-H\right]^{+}-Z \geq \omega L+(H-L) \psi \quad \text { if } \mathbb{I}=0
\end{gathered}
$$




$$
W \geq e H+\psi\left[L^{-}-H\right]^{+}
$$

Where the control variable $\mathbb{I}$ takes the value of 1 if the entrepreneur liquidates the firm in period 2 or the value of 0 if she does not liquidate.

The FOC of this problem is similar to the FOC of the original problem (equation 5), but with an additional term (the first one). For the case when $Z^{L}<\bar{Z}:{ }^{9}$

$$
\begin{array}{r}
0=\left(\psi-\frac{\psi(A-\omega)\left(L^{-}-H\right)}{(\bar{Z}-\underline{Z})}\right) \mathbb{1}_{\left\{L^{-}>H\right\}}-e+(A-\omega) \int_{\underline{Z}}^{Z^{F}} d G(z)+ \\
\int_{Z^{F}}^{Z^{L}}\left[(A-\omega) \frac{-(e+\psi)}{\omega-\psi}-\psi\left(1-\frac{-(e+\psi)}{\omega-\psi}\right)\right] d G(z)
\end{array}
$$

Appendix 3 shows the details of this derivation.

The term $\psi \mathbb{1}_{\left\{L^{-}>H\right\}}$ represents the standard incentive to reduce firing created by the presence of firing costs. If the entrepreneur has a strong financial position $(W \geq \bar{W})$, then the presence of firing costs will have the standard effect. Note that adding a positive term to the FOC implies that $H^{*}$ has to increase in order to balance the FOC.

When financial restrictions are present, the term $\psi \mathbb{1}_{\left\{L^{-}>H\right\}}$ is counter-balanced with the term $-\frac{\psi(A-\omega)\left(L^{-}-H\right)}{(\bar{Z}-\underline{Z})} \mathbb{1}_{\left\{L^{-}>H\right\}}$, which represents the cost associated to the worsening of the firm's liquidity position. If this last term is sufficiently negative, the incentive to reduce firing would become an incentive to increase firing.

In sum, the effect behind the standard argument that firing costs reduce destruction is also present in the model shown in this paper. However, the resulting effect is the same only for financially unrestricted firms. For financially restricted firms, the fact that $L^{-}>H^{*}$ can either i) create an incentive to reduce destruction, but with less intensity than for unrestricted firms, or ii) become an incentive to increase destruction.

These results suggest that the differentiated effect of firing costs on financially restricted firms—a relatively stronger downward scaling effect compared to financially unrestricted firms-is present at the creation margin as well as at the destruction margin.

\footnotetext{
${ }^{9}$ When $Z^{L}=\bar{Z}$, the additional term is $\left(\psi-\frac{\psi(A-\omega)(e+\omega)\left(L^{-}-H\right)}{(\omega-\psi)(\bar{Z}-\underline{Z})}\right) \mathbb{1}_{\left\{L^{-}>H\right\}}$. When $Z^{F}=\bar{Z}$, the additional term is $\psi \mathbb{1}_{\left\{L^{-}>H\right\}}$.
} 


\section{EMPirical AnAlysis}

The main conclusion from the theoretical model says that firing costs have a stronger negative effect on production levels when financial restrictions are present. I study this conclusion empirically by testing the null hypothesis that the effect of firing costs does not depend on the presence of financial restrictions, controlling for both the individual effect of firing costs and the individual effect of financial restrictions. This hypothesis is tested using two different empirical strategies.

The first empirical strategy uses industry level data for a country-industry (manufacturing sector) and tests whether the effect of firing costs on industries' value added depends on the degree of liquidity needs in each industry. Borrowing from the methodology proposed by Rajan and Zingales (1998), the presence of financial restrictions is identified using cross-industry differences in the degree of liquidity requirements implied by their technology of production. The legal level of firing costs in each country, as defined by its labor law, is used as the source for layoff costs variation. Using regression analysis, I test the interactive effect of firing costs and liquidity requirement on industries' value added (measured as their corresponding share of national manufacturing value added).

One advantage of this approach is that it allows the econometrician to control for country characteristics. This is important because country characteristics, such as financial and other labor institutional arrangements, could be correlated with the outcome measure and the legal level of firing costs, and as a result, could produce biased estimates. Since firing costs represent a country level characteristic, many cross-country studies that analyze the effect of firing costs do not control for this feature. ${ }^{10}$ Another advantage of this strategy is that it relies on an exogenous source of financial restrictions variation. Centering on firms' characteristics, such as firms' levels of debt or financial ratios, could create endogeneity problems: these characteristics could determine a firm's access to credit markets, but they are at the same time also determined by the firm's behavior.

This empirical strategy is not free of limitations. First, labor laws are not necessarily applied or supervised homogeneously across countries, which could lead to measurement errors. Second, the identification strategy regarding financial restrictions requires the assumption that the technological differences across industries are common across countries (aggregate differences in these measures across countries do not pose a problem), and that they can be computed by analyzing the behavior of firms operating in well developed financial markets (more on this later). Third, studying industry data is an indirect way of analyzing firm behavior. A more direct approach would be to study firm-level databases (manufacturing) available for some countries. However, most of these databases use plants as their unit of analysis. Plants is not the relevant unit to

\footnotetext{
${ }^{10}$ This can also be the case for country-time panel data sets. As Layard (1990) states, "Unfortunately, changes in severance pay laws are quite rare, so the variation necessary to estimate within-country effects with great precision is not likely to be present in these data." (His panel consists of 22 countries and 29 years.)
} 
address financial issues related to the plants' production level because it does not necessarily characterize the financial entity associated with that level of production. Therefore, using plants undermines the quality of the variable size as a proxy for firms' difficulty in accessing external sources of finance (as opposed to using firms as the unit of analysis).

The second empirical strategy uses a country-sectoral (retail and wholesale trade) panel data with desegregate information for different types of firms according to size, and tests whether the effect of firing costs on firms' value added depends on firms' size — with the understanding that small firms tend to have more limited access to external sources of finance. Firms' value added is measured as their share of national value added in their corresponding sector.

Using a difference in difference approach, I study the difference between small firms' value added in a labor intensive sector (retail) and small firms' value added in a labor un-intensive sector (wholesale). Contrasting two sectors allows us to control for country characteristics, which, as mentioned before, is important for this type of estimations. The identification strategy assumes that the liquidity effect of firing costs is less important in the labor un-intensive sector-in the extreme case of a firm that uses no labor, the liquidity effect of firing costs is zero. The advantage of using retail and wholesale sector is that they differ significantly in their labor to capital ratio, and that in most economies both are large sectors and belong to the same supply chain (more on this later).

Many of the issues discussed for the first empirical strategy apply to this second set of estimates as well. One further challenge in this case is how should small firms be defined. More than one criterion can be used to identify small firms (e.g.: total sales, total assets, number of employees) and surely no criterion equally applies for every industry or firm. To address this issue, I use the number of employees as a criterion to identify small firms - it is an easy variable to measure and is the most standard criterion used - and define a small firm as one employing fewer than 250 employees-following a large number of sources that use firms' size in order to classify firms with limited access to credit markets and data availability. Using the number of employees is also consistent with the identification strategy since many labor laws define exemptions for firms with fewer than 10-20 employees.

In sum, this paper presents two different econometric analyses that study the interactive effect of firing costs and financial restrictions. Although several of their features are new to the literature, these analyses are not free from some of the common econometric challenges present in the labor and corporate finance literature.

In what follows, sections III.A and III.B present the methodology and the results of the first and second set of estimates, respectively. 


\section{A. Empirical Analysis: Liquidity Requirements}

Let $Y_{i j}$ be the share of industry $i$ 's value added in country $j$ 's total manufacturing value added. The first empirical model estimated is based on the following reduced-form equation:

$$
Y_{i j}=\alpha_{i}+\alpha_{j}+\beta_{1} F C_{j} \cdot L R_{i}+\beta_{2} Z_{i j}+\eta_{i j}
$$

where the variable $F C_{j}$ measures firing costs faced by firms in country $j ; L R_{i}$ measures the degree of liquidity requirements implied by the specific technology of production of industry $i$; $Z_{i j}$ is a set of control variables; $\alpha_{j}$ and $\alpha_{i}$ denote country and industry aggregate effects, respectively.

The coefficient $\beta_{1}$ is interpreted as the differential effect that firing costs have on industries' behavior, according to their different degrees of liquidity requirements (implied by their technology of production). A value of $\beta_{1}$ equal to zero would imply that empirically the effect of firing costs does not change as financial restrictions change.

\section{Measure of liquidity requirements}

I follow Rajan and Zingales (1998) methodology to identify technological characteristics of industries. They compute a financially related ratio for each US listed firm, and then construct the industry index as the median of all the observations within each industry. They propose US listed firms as a benchmark by which to measure financially related characteristics because the US financial market is the most efficient credit market in the world, and because listed firms are usually those with better access to financial markets. Therefore, the observed behavior of the firms used to construct the index is as close as possible to the behavior dictated by their technology of production.

For the present analysis, I use two different financially related ratios: Rajan and Zingales (1998) measure of External Financial Dependence (EFD for short) and Gitman (74) measure of Cash Conversion Cycle (CCC for short; see Raddatz (05) for a measure of CCC at industry level). The former index captures the timing and amounts of cash outflow and inflows related to investment and production, to assess liquidity requirements related to the overall investing process. The latter index captures the length in days between the cash outflow from input expenses and the cash inflow from sales, to assess liquidity requirements related to the production process.

These liquidity requirements indexes are constructed as follows: i) EFD is computed as the median observation, among all US listed firms in each industry, of the ratio $\frac{\text { capital expenditures-cash flow from operations }}{\text { capital expenditures }}$, (period 1980-89); ii) CCC is constructed in a similar fashion to EFD, and it is defined as days in inventories plus days 
in receivables minus days in payables. Days in inventories is computed as total inventories 365 , days in receiv-

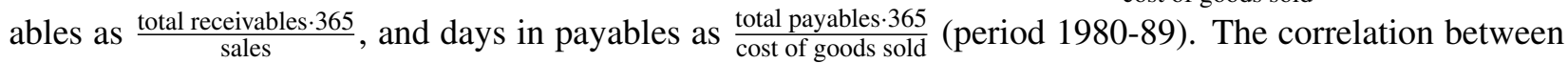
EFD and CCC is 0.08 .

\section{Data and estimation}

The sample consists of 40 countries and 28 manufacturing industries. To control for the quality of the data, all countries included have a per capita GDP higher than $\$ 1000$ in 1985 (1985 dollars). See Table A1 and A2 in Appendix 4 for the composition of the sample.

The dependent variable $Y_{i j}$ is defined as industry $i$ 's share of total value added in country $j$ 's manufacturing sector. It is computed as the median observation within the period 1986-1995. Value added data is obtained from the Industrial Statistics Database (UNIDO 2005, Rev2), which provides a country-year panel dataset with disaggregated information for 28 industries across the manufacturing sector.

The source of firing costs variation used is the legal levels of firing costs in each country as defined by its labor law. Legal levels of firing costs are obtained from Botero et al. (03). The variable $F C_{j}$ measures the level of severance and penalty payments, in weeks of pay, associated with firing a worker for economic reasons in country $j$.

The set of variables $Z_{i j}$ contain controls that intend to capture financial effects related to the industry variables EFD and CCC. This set includes the interaction between the level of each country's financial development with each measure of liquidity requirements (EFD and CCC). Financial development is measured as domestic credit provided by the banking sector (fraction of GDP in 1985, World Development Indicators). The correlation between firing costs and financial development is -0.10 .

The econometric approach is based on a panel data estimation with country and industry fixed effects, and robust to a heteroscedastic error structure. The presence of fixed effects at both industry and country level allows us to control for general country characteristics, such as the degree of financial development, aggregate productivity, labor laws, etc., and for general industry characteristics, such as industry specific factors.

\section{Results}

\section{Main results}

Columns 1 and 2 in Table 1 present the main empirical result of the first set of estimates: The estimated coefficient $\hat{\beta_{1}}$, associated with the interaction between firing costs and financial restrictions in equation 14 , is negative and significant. This is result holds for both variables associated with financial restrictions, EFD 
Table 1. The Effect of the Interaction between Firing Costs and Liquidity Requirements: Main Results

Dependent Variable: Industry value added over total value added in manufacturing sector

\begin{tabular}{|c|c|c|c|c|c|}
\hline & (1) & (2) & (3) & (4) & (5) \\
\hline $\begin{array}{c}\text { Firing Costs } * \text { External Financial } \\
\text { Dependence }\end{array}$ & $\begin{array}{c}-0.113 \\
(0.035)^{* *}\end{array}$ & & $\begin{array}{c}-0.111 \\
(0.034)^{* *}\end{array}$ & & $\begin{array}{c}-0.099 \\
(0.030)^{* *}\end{array}$ \\
\hline Firing Costs * Cash Conversion Cycle & & $\begin{array}{c}-0.131 \\
(0.055)^{* *}\end{array}$ & & $\begin{array}{c}-0.129 \\
(0.055)^{* *}\end{array}$ & $\begin{array}{c}-0.121 \\
(0.053)^{* *}\end{array}$ \\
\hline $\begin{array}{l}\text { Financial Development } * \text { External } \\
\text { Financial Dependence }\end{array}$ & $\begin{array}{c}0.023 \\
(0.006)^{* *}\end{array}$ & & $\begin{array}{c}0.020 \\
(0.005)^{* *}\end{array}$ & $\begin{array}{c}0.021 \\
(0.005)^{* *}\end{array}$ & $\begin{array}{c}0.020 \\
(0.005)^{* *}\end{array}$ \\
\hline $\begin{array}{c}\text { Financial Development } * \text { Cash } \\
\text { Conversion Cycle }\end{array}$ & & $\begin{array}{c}0.032 \\
(0.007)^{* *}\end{array}$ & $\begin{array}{c}0.031 \\
(0.007)^{* *}\end{array}$ & $\begin{array}{c}0.030 \\
(0.007)^{* *}\end{array}$ & $\begin{array}{c}0.030 \\
(0.007)^{* *}\end{array}$ \\
\hline $\mathrm{N}$ & 1066 & 1066 & 1066 & 1066 & 1066 \\
\hline $\mathrm{R} 2$ & 0.4808 & 0.4915 & 0.4945 & 0.4966 & 0.4996 \\
\hline Countries & 40 & 40 & 40 & 40 & 40 \\
\hline Industries & 28 & 28 & 28 & 28 & 28 \\
\hline
\end{tabular}

Robust standard errors in parentheses: * significant at 10\%,** significant at 5\%. Fixed effects control for country and industry unobserved characteristics.

and CCC.

This empirical evidence indicates that firing costs have a differentiated effect which depends on the presence of financial restrictions. In particular, a negative value of $\hat{\beta}_{1}$ indicates that an increase in firing costs has a relatively stronger negative effect in industries with higher financial requirements. Note that if financial markets would work perfectly, and as a result firms would not demand liquidity for insurance purposes, the expected value of $\hat{\beta_{1}}$ would be zero.

The results of the core estimation also hold in a nested environment where both interactive terms are included in the regression, as well as both financial controls (Column 5 in Table 1). This estimation suggests that both measures, EFD and CCC, are capturing different dimensions of financial restrictions.

Using this last estimation, I compute the economic effect associated with the liquidity effect of firing costs resulting from this empirical evidence. A one week reduction in firing costs is associated with a $0.86 \%$ (EFD) and $1.14 \%$ (CCC) growth differential between an industry more affected by the liquidity service effect and an industry less affected. The distance between a more affected and a less affected industry is computed as one standard deviation in the corresponding variable used to measure liquidity requirements.

The results for the control variables in $Z$ in all estimations are consistent with theory and with previous empirical evidence. The positive sign of these estimates indicates that industries with higher financial needs 
benefit more from financial development (Rajan and Zingales 1998).

\section{Robustness checks}

This subsection presents alternative estimates for equation 14 that control for industries' labor intensity and countries' overall quality of institutions.

Firing costs could have a differentiated effect depending on the industries' degree of labor intensity. Column 1 and 2 in Table 2 report the estimates of $\hat{\beta}_{1}$ controlling for the interaction between firing costs and industries' level of labor intensity. The labor intensity ranking across industries is constructed as the median value of the ratio between the number of employees in US industry $i$ to gross fixed capital formation in US industry $i$ (period 1986 and 1995, Industrial Statistics Database). Gross fixed capital formation is deflated by the US nonresident gross private domestic investment deflator. The correlation between labor intensity and EFD, and between labor intensity and CCC, is -0.22 and 0.37 , respectively.

The negative coefficient of the interactive term between firing costs and liquidity requirements reported in Table 2 confirms the main result presented in Table 1: Financial restrictions moderate the effect of firing costs, and in particular, industries with higher liquidity requirements suffer a relatively stronger negative effect of firing costs. This allows us to reject the possibility that the liquidity requirement variables (EFD and $\mathrm{CCC}$ ) are working as proxies for the industries' labor intensity.

The coefficient related to the interaction between firing costs and labor intensity is negative and significant when using the EFD measure. This could be attributed to the negative efficiency effect of firing costs in resource allocation, in particular with respect to the labor factor. However, this result is not found when using the CCC measure. One possible explanation is the positive correlation between CCC and labor intensity.

Legal levels of firing costs could be correlated with other institutional arrangement that can affect firms with higher dependence on external sources of finance (in addition to the degree of financial development). To control for this effect, I estimate equation 14 adding the interactive term between liquidity requirements and a general index of countries' rule of law, where higher means more rule of law (Knack and Keefer 1995). The rule of law variable measures the citizens' willingness to accept the established institutions, to implement laws, and to adjudicate disputes. This variable also allows us to control for potential measurement error related to the difference in enforcement and supervision of labor laws across countries. The correlation between rule of law and firing costs, and between rule of law and financial development, is -0.31 and 0.25 , respectively.

The third and fourth columns in Table 2 show the estimation of equation 14 controlling for the interaction between rule of law and liquidity requirements. The results are consistent with the previous results from Table 1 and Table 2, suggesting the presence of the liquidity service effect of firing costs. The coefficient 
Table 2. The Effect of the Interaction between Firing Costs and Liquidity Requirements: Robustness Checks

Dependent Variable: Industry value added over total value added in manufacturing sector

\begin{tabular}{|c|c|c|c|c|c|c|}
\hline & (1) & (2) & (3) & (4) & (5) & (6) \\
\hline $\begin{array}{c}\text { Firing Costs } * \text { External Financial } \\
\text { Dependence }\end{array}$ & $\begin{array}{c}-0.124 \\
(0.036)^{* *}\end{array}$ & & $\begin{array}{c}-0.101 \\
(0.030)^{* *}\end{array}$ & $\begin{array}{c}-0.076 \\
(0.035)^{* *}\end{array}$ & & $\begin{array}{c}-0.065 \\
(0.032) * *\end{array}$ \\
\hline $\begin{array}{c}\text { Firing Costs } * \text { Cash Conversion } \\
\text { Cycle }\end{array}$ & & $\begin{array}{c}-0.136 \\
(0.058)^{* *}\end{array}$ & $\begin{array}{c}-0.118 \\
(0.055)^{* *}\end{array}$ & & $\begin{array}{c}-0.104 \\
(0.059)^{*}\end{array}$ & $\begin{array}{c}-0.097 \\
(0.057)^{*}\end{array}$ \\
\hline Firing Costs * Labor Intensity & $\begin{array}{c}-0.505 \\
(0.255)^{* *}\end{array}$ & $\begin{array}{c}0.172 \\
(0.230)\end{array}$ & $\begin{array}{l}-0.071 \\
(0.218)\end{array}$ & & & \\
\hline $\begin{array}{c}\text { Rule of Law * External Financial } \\
\text { Dependence }\end{array}$ & & & & $\begin{array}{c}0.543 \\
(0.182)^{* *}\end{array}$ & & $\begin{array}{c}0.51 \\
(0.177)^{* *}\end{array}$ \\
\hline $\begin{array}{c}\text { Rule of Law * Cash Conversion } \\
\text { Cycle }\end{array}$ & & & & & $\begin{array}{c}0.405 \\
(0.258)\end{array}$ & $\begin{array}{c}0.371 \\
(0.253)\end{array}$ \\
\hline $\begin{array}{c}\text { Financial Development } * \text { External } \\
\text { Financial Dependence }\end{array}$ & $\begin{array}{c}0.020 \\
(0.005)^{* *}\end{array}$ & $\begin{array}{c}0.021 \\
(0.005)^{* *}\end{array}$ & $\begin{array}{c}0.020 \\
(0.005)^{* *}\end{array}$ & $\begin{array}{c}0.016 \\
(0.006)^{* *}\end{array}$ & $\begin{array}{c}0.021 \\
(0.005)^{* *}\end{array}$ & $\begin{array}{c}0.016 \\
(0.006) * *\end{array}$ \\
\hline $\begin{array}{c}\text { Financial Development } * \text { Cash } \\
\text { Conversion Cycle }\end{array}$ & $\begin{array}{c}0.0310 \\
(0.007)^{* *}\end{array}$ & $\begin{array}{c}0.0300 \\
(0.007)^{* *}\end{array}$ & $\begin{array}{c}0.0300 \\
(0.007)^{* *}\end{array}$ & $\begin{array}{c}0.0310 \\
(0.007)^{* *}\end{array}$ & $\begin{array}{c}0.0270 \\
(0.007)^{* *}\end{array}$ & $\begin{array}{c}0.0270 \\
(0.007)^{* *}\end{array}$ \\
\hline $\mathrm{N}$ & 1066 & 1066 & 1066 & 1066 & 1066 & 1066 \\
\hline $\mathrm{R} 2$ & 0.4955 & 0.4968 & 0.4996 & 0.4978 & 0.4989 & 0.5048 \\
\hline Countries & 40 & 40 & 40 & 40 & 40 & 40 \\
\hline Industries & 28 & 28 & 28 & 28 & 28 & 28 \\
\hline
\end{tabular}

Robust standard errors in parentheses: * significant at $10 \%, * *$ significant at $5 \%$. Fixed effects control for country and industry unobserved characteristics.

related to the interaction between firing costs and rule of law is positive, but significant only when using the EFD measure. A positive coefficient reflects the expected positive effect of rule of law in fostering financial intermediation (i.e.: contracts are more easily enforced).

\section{Asset collateralization}

The previous empirical exercises concentrate on measures of liquidity requirements. An alternative way of measuring financial restrictions is to look at the firm's ability to collateralize its assets: higher asset collateralization means better access to external financial resources.

To test this idea I use Braun's (2003) index of collateralization or degree of tangibility of industries' assets. In a similar fashion to Rajan and Zingales (1998), he uses US listed firms to estimate the industries' availability of tangible assets as a measure of collateral. The ratio computed is $\frac{\text { net property, plant, and equipment }}{\text { total assets }}$ I will refer 
Table 3. The Effect of the Interaction between Firing Costs and Liquidity Requirements: Asset Collateralization

Dependent Variable: Industry value added over total value added in manufacturing sector

\begin{tabular}{|c|c|c|c|c|c|}
\hline & (1) & (2) & (3) & (4) & (5) \\
\hline Firing Costs $*$ Tangibility & $\begin{array}{c}0.337 \\
(0.143)^{* *}\end{array}$ & $\begin{array}{c}0.339 \\
(0.139)^{* *}\end{array}$ & $\begin{array}{c}0.366 \\
(0.159)^{* *}\end{array}$ & $\begin{array}{c}0.306 \\
(0.152)^{* *}\end{array}$ & $\begin{array}{c}0.302 \\
(0.153)^{* *}\end{array}$ \\
\hline $\begin{array}{c}\text { Firing Costs } * \text { External Financial } \\
\text { Dependence }\end{array}$ & & $\begin{array}{c}-0.114 \\
(0.034)^{* *}\end{array}$ & $\begin{array}{c}-0.11 \\
(0.033)^{* *}\end{array}$ & $\begin{array}{c}-0.114 \\
(0.034)^{* *}\end{array}$ & $\begin{array}{c}-0.079 \\
(0.035)^{* *}\end{array}$ \\
\hline Firing Costs * Labor Intensity & & & $\begin{array}{c}0.181 \\
(0.265)\end{array}$ & & \\
\hline Rule of Law * Tangibility & & & & $\begin{array}{l}-0.553 \\
(0.643)\end{array}$ & $\begin{array}{l}-0.593 \\
(0.643)\end{array}$ \\
\hline $\begin{array}{c}\text { Rule of Law * External Financial } \\
\text { Dependence }\end{array}$ & & & & & $\begin{array}{c}0.549 \\
(0.188)^{* *}\end{array}$ \\
\hline Financial Development $*$ Tangibility & $\begin{array}{c}-0.058 \\
(0.018)^{* *}\end{array}$ & $\begin{array}{c}-0.058 \\
(0.017)^{* *}\end{array}$ & $\begin{array}{c}-0.058 \\
(0.017)^{* *}\end{array}$ & $\begin{array}{c}-0.054 \\
(0.018)^{* *}\end{array}$ & $\begin{array}{c}-0.053 \\
(0.018)^{* *}\end{array}$ \\
\hline $\begin{array}{l}\text { Financial Development } * \text { External } \\
\text { Financial Dependence }\end{array}$ & & $\begin{array}{c}0.023 \\
(0.005)^{* *}\end{array}$ & $\begin{array}{c}0.023 \\
(0.005)^{* *}\end{array}$ & $\begin{array}{c}0.023 \\
(0.005)^{* *}\end{array}$ & $\begin{array}{c}0.019 \\
(0.006)^{* *}\end{array}$ \\
\hline $\mathrm{N}$ & 1066 & 1066 & 1066 & 1066 & 1066 \\
\hline $\mathrm{R} 2$ & 0.4838 & 0.495 & 0.4951 & 0.4957 & 0.4991 \\
\hline Countries & 40 & 40 & 40 & 40 & 40 \\
\hline Industries & 28 & 28 & 28 & 28 & 28 \\
\hline
\end{tabular}

Robust standard errors in parentheses: * significant at 10\%,** significant at 5\%. Fixed effects control for both, country and industry unobserved characteristics.

to this index as TAN. The correlation of TAN with EFD, CCC, and labor intensity is $0.01,-0.77$, and -0.51 , respectively. Given the high correlation of TAN with CCC, I exclude the latter from this set of estimations.

Table 3 replicates the previous empirical results using the TAN index. Since higher TAN means better access to financial markets, a positive coefficient would be consistent with the liquidity service effect. The results in the first column of Table 3 show a positive and significant estimate for the coefficient of interest, which indicate that an increase in firing costs has a relatively stronger negative effect on industries with lower levels of asset collateralization. The next columns replicate the robustness checks done for the estimations using the measures of liquidity requirement, and show that the main conclusion holds. 


\section{B. Empirical Analysis: Small Firms}

This section studies the effect of firing costs on of small firms' value added (measured as their share of total sector value added). I use firms' size as a proxy for firms' difficulty in accessing external sources of finance, and I control for country characteristics by comparing small firms' value added in a relatively labor intensive sector (retail trade) with small firms' value added in a relatively labor un-intensive sector (wholesale trade).

The advantage of using retail and wholesale sectors lies in three factors: i) they use labor and capital in significantly different proportions (the average labor to capital ratio in the US retail sector during the period 1990-1999 is 4.4 times higher than the average ratio in the US wholesale sector); ii) both are important sectors in most economies; and iii) both sectors belong to the same supply chain. Note that I define both sectors excluding sales as well as maintenance and repair of motor vehicles. ${ }^{11} 12$

The empirical analysis is based on the following formulation. Let $S_{i j}$ be the share of small firms' value added in sector $i$ of country $j$. The empirical model estimated is given by the following equation:

$$
S_{i j}=\alpha_{i}+\alpha_{j}+\theta_{1} F C_{j} \cdot D_{i}+\mu_{i j}
$$

where the variable $F C_{j}$ measures firing costs faced by firms in country $j ; D_{i}$ is a dummy variable that takes a value of one in the labor intensive sector and zero otherwise; $\alpha_{j}$ and $\alpha_{i}$ denote country and sector aggregate effects, respectively.

The coefficient $\theta_{1}$ is interpreted as the differentiated effect that firing costs have on small firms' value addedcontrolling for country effects by making the contrast with the effect observed in a significantly less laborintensive sector.

Following the discussion in the previous section, it is important to take into consideration the levels of liquidity requirements in both sectors. If the liquidity requirements are higher in the wholesale sector, then the expected sign of $\theta_{1}$ is ambiguous. On the one hand, higher firing costs could imply a heavier burden for small firms in wholesale because of higher liquidity requirements, but at the same time, a lower burden for these type of firms because of lower labor intensity. To address this issue, I study the level of EFD and CCC in both sectors using Rajan and Zingales (1998) methodology. The estimates show that wholesale has a lower EFD and a higher CCC. For both measure of liquidity requirement, the difference between the estimate for

\footnotetext{
${ }^{11}$ Using US national accounts and labor statistics, I compute the ratio of labor to capital in the retail and wholesale sectors. Labor is measured as employment and capital as stock of structure, equipment, and software. Yearly figures are appropriately deflated using the price indexes for structure and for equipment and software.

${ }^{12}$ Aggregating all 12 countries included in the sample (see next section), value added in the wholesale sector in 1999 represented $5.6 \%$ of total GDP, and value added in the retail sector represented $4.6 \%$.
} 
Figure 2. Difference in Difference

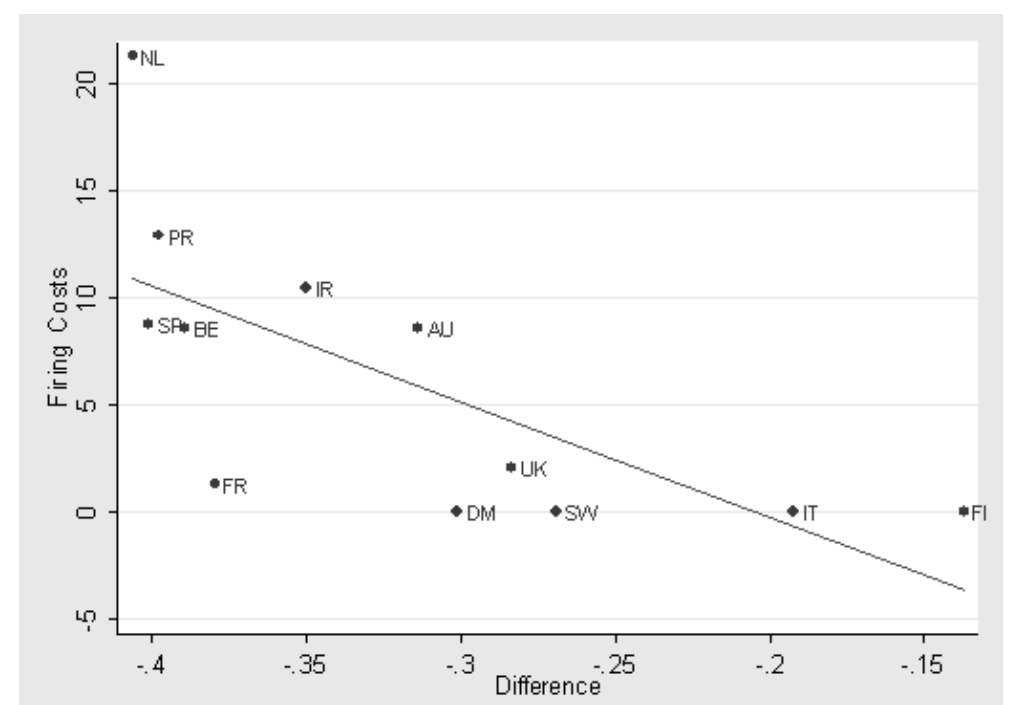

Note: The figure plots the correlation between firing costs and the difference between small firms' share of value added in the retail and wholesale sectors. The correlation value is -0.69 .

the whole sector minus the estimate for the retail sector is, however, small: -0.18 for EFD and 0.06 for CCC (these differences are expressed as shares of the max-min range observed among manufacturing industries for EFD and CCC, respectively).

\section{Data and results}

The sample consists of 12 EU-15 countries with available sectoral data on aggregate value added for firms of different sizes, where size is defined by the number of employees working in the firm (see Table A3 in Appendix 4 for the composition of the sample). The data is obtained from Eurostat's Structural Business Statistics and covers the period 1996-2001.

Many labor laws define exemptions for firms with fewer than 10-20 employees; this exemption level varies across countries. For this reason, I define small firms as firms employing between 10 and 249 employees. Robustness checks are performed using the alternative range of 20 to 249 employees.

Figure 2 provides a first look at the data. It illustrate the difference in difference estimation, but instead of grouping countries into high and low firing costs groups, it plots the difference $S_{R j}-S_{W j}$ against the level of firing costs in country $j$ (the data is for the year 1999, the only year with data for all 12 countries). This figure suggests that the impact of firing costs is relatively stronger in more financially restricted firms. Note that if financial restrictions play no role in determining the effect of firing costs, no correlation would be expected. 
Table 4. The Effect of Firing Costs on Small Firms' Market Participation: Main Results

Dependent Variable: Small firms' value added in sector $i$ over total value added in sector $i$ ( $i=$ Retail, Wholesale)

\begin{tabular}{|c|c|c|c|c|c|c|}
\hline & (1) & (2) & (3) & (4) & $(5)$ & (6) \\
\hline & \multicolumn{6}{|c|}{ Definition of a small firm (\# of employees) } \\
\hline & $10-249$ & $10-249$ & $20-249$ & $20-249$ & $1-9$ & $1-9$ \\
\hline $\begin{array}{c}\text { Firing Costs } * \text { Sector } \\
\text { Dummy }(\text { Retail }=1)\end{array}$ & $\begin{array}{c}-0.009 \\
(0.003)^{* *}\end{array}$ & $\begin{array}{c}-0.008 \\
(0.003)^{* *}\end{array}$ & $\begin{array}{c}-0.006 \\
(0.002)^{* *}\end{array}$ & $\begin{array}{c}-0.005 \\
(0.003)^{* *}\end{array}$ & $\begin{array}{c}0.008 \\
(0.003)^{* *}\end{array}$ & $\begin{array}{c}0.009 \\
(0.003)^{* *}\end{array}$ \\
\hline $\mathrm{N}$ & 24 & 98 & 24 & 98 & 24 & 98 \\
\hline $\mathrm{R} 2$ & 0.9714 & 0.9479 & 0.9768 & 0.9582 & 0.9333 & 0.9308 \\
\hline Countries & 12 & 12 & 12 & 12 & 12 & 12 \\
\hline Years & 1 & 6 & 1 & 6 & 1 & 6 \\
\hline
\end{tabular}

Robust standard errors in parentheses: * significant at 10\%,** significant at 5\%. Fixed effects control for sector, country, and year unobserved characteristics. The standard errors are clustered at the country level for the estimates with more than one year of data.

The negative correlation observed in Figure $2(-0.69)$ is confirmed with the estimates of the parameter $\theta$ in equation 15. The first column in Table 4 shows the estimate of $\theta$ using only data for 1999, while the second column shows the result for the same estimation using all available data with standard errors clustered at the country level. The main conclusion from these estimates is the following: Firing costs are associated with a relatively stronger negative effect on small firms' market participation.

Using this last estimation, I compute the economic effect associated with the liquidity effect of firing costs resulting from this empirical evidence. A one week reduction in firing costs is associated with a $0.8 \%$ increase in the share of small firms's value added in the retail sector (relative to the observed change in the wholesale sector).

Columns 3 and 4 in Table 4 replicate the estimations reported in the first two columns of Table 4 redefining small firms as firms employing 20 to 249 employees. The results are similar to the ones found with the alternative definition of 10 to 249 employees.

A second robustness check is performed by studying the share of value added associated with firms employing between 1 and 9 employees. Since labor laws exempt these firms from layoff costs, we should not find the negative effect of firing costs that we find in the previous estimations. These estimates are reported in the fifth and sixth columns of Table 4, showing a positive instead of negative effect of firing costs. This result is consistent with a negative effect of firing costs on financially restricted firms, and suggests a size and/or sector selection among small firms, possibly to avoid the cost of being subject to the full extent of the labor law. 


\section{Conclusion}

This work draws attention to a new effect of labor policy, in particular firing costs, on firms' behavior. In short, the presence of firing costs reduces the ability to generate net liquidity through firing, and decreases the value of labor's liquidity service. As a result, there is a differentiated effect of firing costs on financially restricted firms - a relatively stronger negative effect on output - which is present both at the creation and destruction margins.

Empirical evidence in line with this channel is presented. Controlling for both the individual effect of firing costs and the individual effect of financial restrictions, I reject the hypothesis that the effect of firing costs does not depend on the presence of financial restrictions. Based on a country-industry (manufacturing) panel data, I find a relatively stronger negative effect of firing costs on the value added of industries with higher liquidity requirements. In addition, using a country-sectoral (retail and wholesale trade) panel data with desegregate information for different types of firms according to size, I find a relatively stronger negative effect of firing costs on small firms' value added.

These results suggest that reductions in dismissal costs could have different effects among different type of firms depending on whether financial restrictions are relevant constraints or not. From a policy perspective, countries with less developed financial sectors, where firms are more likely to face limited access to credit markets, could, ceteris paribus, benefit more from reducing firing costs. This effect would be in addition to the efficiency gains associated with the standard efficiency loss of firing costs (Bentolila and Bertola 1990 and Lazear 1990).

Similarly, firms facing relevant financial constraints within a country could, ceteris paribus, benefit more from a reduction of firing costs. This suggests that, compared to a homogeneous labor policy that establishes identical dismissal costs for all types of firms, a heterogeneous labor policy that establishes lower firing costs for financially restricted firms could, without changing the average level of job turnover in the economy, increase the incentive to allocate capital and labor based on productivity considerations (as opposed to financial concerns).

In fact, labor laws in many countries exempt smaller firms from employment protection measures-small firms are generally considered to be firms with limited or no access to credit markets (compared to large firms). In this regard, the model developed in this paper could offer a theoretical justification for this type of differentiated policy structures.

Overall, the role of firms' financial restrictions in determining labor policy effects suggests an interesting and policy-relevant set of issues that warrant further research and that could become an input in labor policy design. 


\section{Appendix I. Deriving the Threshold $W^{B}$}

\section{A. The case when $Z^{L} \leq \bar{Z}$}

Assume a solution $H^{*}$, such that $Z^{L} \leq \bar{Z}$. From the first order condition in equation 5, we know that such a solution has to be of the following form.

$$
H^{*}=\frac{W-\bar{Z}+\frac{(A-\omega-e)}{(A-\omega)}(\bar{Z}-\underline{Z})}{e+w+\frac{(e+\psi)}{(A-\omega+\psi)}\left(A-\omega+(e+\omega) \frac{\psi}{e+\psi}\right)}
$$

To be consistent with the above statement, the following inequality has to hold.

$$
W-H^{*}(e+\psi \theta) \leq \bar{Z}
$$

Where $H^{*}$ is given by equation 16 , and $\theta \equiv \frac{A}{A-\omega+\psi}$.

Working out the inequality in equation 17 , we can derive a condition for $W$, such that the solution given by equation 16 is consistent with the statement in equation 17. This condition is represented in equation 18 .

$$
W \leq \bar{Z}+\frac{(A-\omega-e)(A e-\omega e+\psi e+A \psi)}{(A-\omega+\psi)(e+\omega)(A-\omega)}(\bar{Z}-\underline{Z})=W^{B}
$$

Note that a strong inequality in condition 17 implies that $W<W^{B}$.

\section{B. The case when $Z^{L}=\bar{Z}$}

Assume a solution $H^{*}$, such that $Z^{L}=\bar{Z}$. From the first order condition in equation 5, we know that such a solution has to be of the following form.

$$
H^{*}=\frac{W-\bar{Z}+\frac{(A-\omega-e)(\omega-\psi)}{(A-\omega+\psi)(e+\omega)}(\bar{Z}-\underline{Z})}{e+w}
$$

To be consistent with the above statement, the following inequality has to hold. 


$$
W-H^{*}(e+\psi \theta) \geq \bar{Z}
$$

Where $H^{*}$ is given by equation 19 , and $\theta \equiv \frac{A}{A-\omega+\psi}$.

Working out the inequality in equation 20, we can derive a condition for $W$, such that the solution given by equation 19 is consistent with the statement in equation 20. This condition is represented in equation 21.

$$
W \geq \bar{Z}+\frac{(A-\omega-e)(A e-\omega e+\psi e+A \psi)}{(A-\omega+\psi)(e+\omega)(A-\omega)}(\bar{Z}-\underline{Z})=W^{B}
$$

In sum, we know from equation 18 that above the threshold $W^{B}$ there is no solution to $H^{*}$, such that $Z^{L}<\bar{Z}$. Likewise, we know from equation 21 that below the threshold $W^{B}$ there is no solution to $H^{*}$, such that $Z^{L}=\bar{Z}$. Therefore, it has to be true that there is only one solution for each level of $W$, and that such solution implies $Z^{L}<\bar{Z}$, for all values of $W<W^{B}$, and $Z^{L}=\bar{Z}$ for all values of $W \geq W^{B}$. 


\section{Appendix II. The Effect of Optimal Scale on the Expected Value of Labor in Period $2\left(\frac{\partial \mathbb{E} L^{*}}{\partial H^{*}}\right)$}

From equation 8 , we can write the expected value of labor in period 2 as:

$$
\mathbb{E} L^{*}=\left\{\begin{array}{cc}
H^{*}-\frac{\left(\bar{Z}-Z^{F}\right)^{2}}{2(\omega-\psi)(\bar{Z}-\underline{Z})} & \text { if } W \geq W^{B} \\
H^{*}\left[\frac{e}{A-\omega}+H^{*} \frac{(e+\psi)}{(A-\omega+\psi)(\bar{Z}-\underline{Z})}\left(A-\omega+(e+\omega) \frac{\psi}{e+\psi}\right)+\right. & \\
\left.H^{*}(\omega-\psi \theta)\left(1-\frac{A-\omega}{2(A-\omega+\psi)}\right)\right] & \text { if } W<W^{B}
\end{array}\right.
$$

Differentiating equation 22:

$$
\frac{\partial \mathbb{E} L^{*}}{\partial H^{*}}= \begin{cases}1-\frac{(e+\omega)\left(\overline{\mathrm{Z}}-Z^{F}\right)}{(\omega-\psi)(\bar{Z}-\underline{Z})}>0 & \text { if } W \geq W^{B} \\ \frac{\mathbb{E} L^{*}}{H^{*}}+H^{*} \frac{(e+\psi)}{(A-\omega+\psi)(\overline{\mathrm{Z}}-\underline{Z})}\left(A-\omega+(e+\omega) \frac{\psi}{e+\psi}\right)+ & \\ H^{*}(\omega-\psi \theta)\left(1-\frac{A-\omega}{2(A-\omega+\psi)}\right)>0 & \text { if } W<W^{B}\end{cases}
$$

For the case when $W \geq W^{B}$, we know that $H^{*}(e+w)=W-\bar{Z}+\frac{(A-\omega-e)(\omega-\psi)}{(A-\omega+\psi)(e+\omega)}(\bar{Z}-\underline{Z})$, which implies that $H^{*}(e+w)-W+\bar{Z}<\frac{(\omega-\psi)}{(e+\omega)}(\bar{Z}-\underline{Z})$ (note that $\left.\frac{(A-\omega-e)}{(A-\omega+\psi)}<1\right)$. This last inequality implies that $\left(\bar{Z}-Z^{F}\right)(e+$ $\omega)<(\omega-\psi)(\bar{Z}-\underline{Z})$, and therefore, that $1-\frac{(e+\omega)\left(\bar{Z}-Z^{F}\right)}{(\omega-\psi)(\bar{Z}-\underline{Z})}>0$

For the case when $W<W^{B}$, it is straight forward to see that the derivative is positive. Just note that $A>\omega$, that $\omega \geq \psi \theta$, and that $\frac{A-\omega}{2(A-\omega+\psi)}<1$.

In sum, an increase in the initial scale of the project (optimal) increases the production level in period 2. 


\section{Appendix III. First Order Condition When $L^{-}>0$}

Following the same steps used to derived the FOC in equation 5, we can write the FOC for the case when $Z^{L}<\bar{Z}$.

$$
\begin{array}{r}
0=\psi \mathbb{1}_{\left\{L^{-}>H\right\}}-e+(A-\omega) \int_{\underline{Z}}^{W-H(e+\omega)-\psi\left[L^{-}-H\right]^{+}} d G(z)+ \\
\int_{W-H(e+\omega)-\psi\left[L^{-}-H\right]^{+}}^{W-H(e+\psi \theta)-\psi\left[L^{-}-H\right]^{+}}\left[(A-\omega) \frac{-(e+\psi)}{\omega-\psi}-\psi\left(1-\frac{-(e+\psi)}{\omega-\psi}\right)\right] d G(z)
\end{array}
$$

The integral $\int_{\underline{Z}}^{W-H(e+\omega)-\psi\left[L^{-}-H\right]^{+}} d G(z)$ can be written as $\int_{\underline{Z}}^{W-H(e+\omega)} d G(z)-\int_{0}^{\psi\left[L^{-}-H\right]^{+}} d G(z)$. Rearranging terms:

$$
\begin{array}{r}
0=\left(\psi-\frac{\psi(A-\omega)\left(L^{-}-H\right)}{(\bar{Z}-\underline{Z})}\right) \mathbb{1}_{\left\{L^{-}>H\right\}}-e+(A-\omega) \int_{\underline{Z}}^{Z^{F}(W, H)} d G(z)+ \\
\int_{Z^{F}(W, H)}^{Z^{L}(W, H)}\left[(A-\omega) \frac{-(e+\psi)}{\omega-\psi}-\psi\left(1-\frac{-(e+\psi)}{\omega-\psi}\right)\right] d G(z)
\end{array}
$$

The FOC condition in equation 25 is identical to the FOC in equation 5 (original problem), except for the additional first term.

When $Z^{L}(W)=\bar{Z}$ an equivalent derivation yields the same type of analysis (see footnote 9). 


\section{Appendix IV. Composition of the Samples}

Table A1. Manufacturing Sample (Countries)

\begin{tabular}{cccc}
\hline Country & Number of Observations & Country & Number of Observations \\
\hline Argentina & 28 & Malaysia & 28 \\
Australia & 28 & Mexico & 26 \\
Austria & 28 & Netherlands & 27 \\
Belgium & 19 & New Zealand & 26 \\
Brazil & 18 & Norway & 28 \\
Canada & 28 & Panama & 25 \\
Chile & 28 & Poland & 28 \\
Colombia & 28 & Portugal & 28 \\
Denmark & 28 & Romania & 27 \\
Ecuador & 28 & Singapore & 26 \\
Finland & 28 & South Africa & 28 \\
France & 26 & Spain & 28 \\
Greece & 28 & Sweden & 28 \\
Hungary & 28 & Switzerland & 13 \\
Ireland & 27 & Tunisia & 22 \\
Israel & 28 & Turkey & 28 \\
Italy & 28 & United Kingdom & 28 \\
Japan & 28 & United States & 28 \\
Jordan & 28 & Uruguay & 28 \\
Korea & 28 & Venezuela & 28 \\
& & Total & 1066 \\
\hline
\end{tabular}


Table A2. Manufacturing Sample (Industries)

\begin{tabular}{|c|c|c|}
\hline ISIC Code & Industry Name & Number of Observations \\
\hline 311 & Food products & 40 \\
\hline 313 & Beverages & 39 \\
\hline 314 & Tobacco & 39 \\
\hline 321 & Textiles & 40 \\
\hline 322 & Wearing apparel, except footwear & 40 \\
\hline 323 & Leather products & 37 \\
\hline 324 & Footwear, except rubber or plastic & 36 \\
\hline 331 & Wood products, except furniture & 40 \\
\hline 332 & Furniture, except metal & 38 \\
\hline 341 & Paper and products & 40 \\
\hline 342 & Printing and publishing & 39 \\
\hline 351 & Industrial chemicals & 40 \\
\hline 352 & Other chemicals & 38 \\
\hline 353 & Petroleum refineries & 36 \\
\hline 354 & Misc. petroleum and coal products & 32 \\
\hline 355 & Rubber products & 40 \\
\hline 356 & Plastic products & 38 \\
\hline 361 & Pottery, china, earthenware & 39 \\
\hline 362 & Glass and products & 35 \\
\hline 369 & Other non-metallic mineral products & 36 \\
\hline 371 & Iron and steel & 40 \\
\hline 372 & Non-ferrous metals & 36 \\
\hline 381 & Fabricated metal products & 37 \\
\hline 382 & Machinery, except electrical & 39 \\
\hline 383 & Machinery, electric & 39 \\
\hline 384 & Transport equipment & 38 \\
\hline 385 & Professional \& scientific equipment & 37 \\
\hline \multirow[t]{2}{*}{390} & Other manufactured products & 38 \\
\hline & Total & 1066 \\
\hline
\end{tabular}


Table A3. EU-15 Sample

\begin{tabular}{cc}
\hline Country & Number of Observations \\
\hline Austria & 10 \\
Belgium & 12 \\
Denmark & 6 \\
Finland & 8 \\
France & 10 \\
Ireland & 2 \\
Italy & 12 \\
Netherlands & 6 \\
Portugal & 10 \\
Spain & 6 \\
Sweden & 8 \\
United Kingdom & 8 \\
Total & 98 \\
\hline
\end{tabular}




\section{References}

Alvarez, F. and M. Veracierto (2001). "Severance Payments in an Economy with Frictions," Journal of Monetary Economics, Vol. 47, No. 3, pp. 477-498.

Bentolila, S. and G. Bertola (1990). "Firing Costs and Labor Demand: How Bad is Eurosclerosis?" Review of Economic Studies, Vol. 57, No. 3, pp. 381-402.

Blanchard, O. (2000). The Economics of Unemployment. Shocks, Institutions, and Interactions. Lionel Robbins Lectures, London School of Economics.

Braun, M. (2003). “Financial Contractibility and Assets' Hardness.” Mimeo, UCLA.

Caballero, R. and M. Hammour (1998). "Jobless Growth: Appropriability, Factor Substitution and Unemployment," Carnegie-Rochester Conference Series on Public Policy, Vol. 48, pp. 51-94.

Davis S., J. Haltiwanger, S. Schuh (1996). “Job Creation and Destruction.” MIT Press, Cambridge, Massachusetts.

Diamond, D. and G. Rajan (2001). "Liquidity Risk, Liquidity Creation, and Financial Fragility: A theory of Banking," Journal of Political Economy, Vol. 109, No. 2, pp. 287-327.

Gitman, L. (1974). "Corporate Liquidity Requirements: A Simplified Approach,” The Financial Review, Vol. 9, pp. 79-88.

Gilchrist, S. and M. Gertler (1994). "Monetary Policy, Business Cycles, and the Behavior of Small Manufacturing Firms," Quarterly Journal of Economics, Vol. 109, No. 2, pp. 309-40.

Hart, O. and J. Moore (1994). “A Theory of Debt Based on the Inalienability of Human Capital,” Quarterly Journal of Economics, Vol. 109, No. 4, pp. 841-879.

Holmstrom, B. and J. Tirole (1998). "Private and Public Supply of Liquidity," Journal of Political Economy, Vol. 106, No. 1, pp. 1-40.

Hopenhayn, H. and R. Rogerson (1993). "Job Turnover and Policy Evaluation: A General Equilibrium Analysis," Journal of Political Economy, Vol. 101, No. 5, pp. 915-938.

Jeong, B. (2003). "The Welfare Effects of Mobility Restrictions," Review of Economic Dynamics, Vol. 6, No. 3, pp. 685-696.

Knack, S. and P. Keefer (1995). "Institutions and Economic Performance: Cross- Country Tests Using Alternative Institutional Measures," Economics and Politics, Vol. 7, No. 3, pp. 207-227.

Lamont, O. (1997). "Cash flow and investment: Evidence from internal capital markets," Journal of Finance, Vol. 52, No. 1, pp. 83-109.

Lazear, E. (1990). “Job Security Provisions and Employment," Quarterly Journal of Economics, Vol. 105, No. 3, pp. 699-726. 
Ljungqvist, L. (2002). "How Do Lay-off Costs Affect Employment?" The Economic Journal, Vol. 112, No. 482, pp. 829-853.

OECD (2004). "Employment Outlook." Organisation for Economic Co-Operation and Development, Paris, France.

Pries, M. and R. Rogerson (2005). "Hiring Policies, Labor Market Institutions, and Labor Market Flows," Journal of Political Economy, Vol. 113, No. 4, pp. 811-839.

Raddatz, C. (2005). "Liquidity Needs and Vulnerability to financial underdevelopment," Journal of Financial Economics, forthcoming.

Rajan, R. and L. Zingales (1998). "Financial Dependence and Growth," American Economic Review, Vol. 88, No. 3, pp. 559-586.

Rauh, J. (2005). "Investment and Financing Constraints: Evidence from the Funding of Corporate Pension Plans," Journal of Finance, forthcoming.

Veracierto, M. (2001). "Employment Flows, Capital Mobility, and Policy Analysis," International Economic Review, Vol. 42, No. 3, pp. 571-595. 